\title{
The Socioeconomic and Ethnic Segregation of Living Conditions in Copenhagen
}

A segregação racial e socioeconómica nas condições de vida em Copenhaga

La ségrégation raciale et socioéconomique dans les conditions de vie à

Copenhague

Iver Hornemann Møller and Jørgen Elm Larsen

\section{OpenEdition}

\section{Journals}

Electronic version

URL: http://journals.openedition.org/rccs/6071

DOI: $10.4000 /$ rccs.6071

ISSN: 2182-7435

\section{Publisher}

Centro de Estudos Sociais da Universidade de Coimbra

\section{Printed version}

Date of publication: 1 December 2015

Number of pages: 7-30

ISSN: 0254-1106

\section{Electronic reference}

Iver Hornemann Møller and Jørgen Elm Larsen, « The Socioeconomic and Ethnic Segregation of Living Conditions in Copenhagen », Revista Crítica de Ciências Sociais [Online], 108 | 2015, Online since 16 December 2015, connection on 19 April 2019. URL : http://journals.openedition.org/rccs/6071 ; DOI : $10.4000 /$ rccs.6071

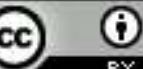




\section{IVER HORNEMANN MØLLER JØRGEN ELM LARSEN}

\section{The Socioeconomic and Ethnic Segregation of Living Conditions in Copenhagen}

The aim of this article is to analyze the discrepancies between certain aspects of living conditions of ethnic Danes and immigrants in Copenhagen. Copenhagen is quite prosperous and fares well in the globalized economy but is at the same time experiencing increasing poverty and ethnic segregation. Differences in income have increased spatial segregation in Copenhagen in terms of housing and education. This segregation is most visible in relation to highly educated Danes and immigrants from non-Western countries. The article first examines poverty at household level and its spatial dimensions. Secondly, it considers other living conditions (for example social networks). Thirdly, it explores immigrants' experiences of, among other things, education, employment and citizenship. It concludes that social cohesion in Copenhagen may be threatened if this segregation continues.

Keywords: Copenhagen (Danmark); immigrants and natives Danes; living conditions; poverty; segregation.

\section{Introduction}

Copenhagen, today, appears to be a resurgent city. It came back to life in the mid-1990s and has shown a marked growth in income and inhabitants, primarily as a result of comprehensive investments in modern housing, a metro, a bridge to Sweden and the rise and spatial dynamics of its service and knowledge-based industries (Andersen and Winther, 2010). Its resurgence is also evident in the city districts that 20 years ago were struggling with the repercussions of a long-term urban crisis. Financially, the city centre was almost doomed in the late 1980s and early 1990s, and the city of Copenhagen was close to bankruptcy (Majoor, 2008). City centre development was undermined by a set of eroding processes that included de-industrialisation, suburbanization, high unemployment rates, high welfare costs, an outdated housing market and strong ethnic and income segregation (Andersen and Winther, 2010). It has now been revitalized and is, 
today, a strong national centre for economic growth (Winter, 2007; Hansen and Winter, 2010). Yet, although the urban upturn remains strong, it is still possible to catch glimpses of national economic problems, such as rising differences in income and increasing poverty in areas with large minorities of immigrants and their descendants from non-Western countries. ${ }^{1}$ These areas are often proclaimed "parallel societies" and "ethnic enclaves" by the media, with immigrants implicitly held responsible for their isolation from wider society and lack of willingness to integrate. The term "immigrants" is used in this article to refer to immigrants and their descendants from non-Western countries only.

The focus of the article is the municipality of Copenhagen and one particular district, Nørrebro, which has one of the highest concentrations of immigrants - on 1st January 2014, 19.2\% of the inhabitants were from non-Western countries (Københavns Kommune, 2014). The main aim is to illustrate and analyse the discrepancies between certain aspects of living conditions for Danes and immigrants. Following the introduction, Section Two presents the analytical tools, the most important of which are Fraser's (1992, 2000, 2008) concepts of recognition, redistribution and political representation. These concepts are related to Honneth's (1995) understanding of recognition, further developed by Mouzelis' (1995) concept of polylogic integration, Titmuss' (1974) concept of positive selectivism, Thompson and Hoggert's (1996) concept of particularism and Sen's (1992) understanding of capability failures. It also considers Wacquant's $(1996,2008)$ concept of advanced marginality, which is seen as a useful tool for studying Nørrebro. In the third section, selected aspects of immigrant and Danish citizens' living conditions are compared, whilst Section Four describes Copenhagen City Council's integration policies. In Section Five these conditions are compared with the help of the analytical tools, leading to the perspectives presented in Section Six.

\footnotetext{
${ }^{1}$ The official classification of immigrants, descendants and Danes is used for legal and statistical purposes. Immigrants are born in a foreign country: their parents do not have Danish citizenship and were not born in Denmark. They are divided into two groups: immigrants from Western and non-Western countries. Western countries are the Nordic and EU countries, Andorra, Liechtenstein, Monaco, San Marino, Switzerland, the Vatican State, Canada, the USA, Australia and New Zealand: all other countries are defined as non-Western. Descendants are born in Denmark. Their parents do not have Danish citizenship and were not born in Denmark. When one or both parents born in Denmark obtain Danish citizenship, their children will no longer be classified as descendants. A person is classified as Danish if one of their parents has Danish citizenship and was born in Denmark (Danmarks Statistik, 2013).
} 


\section{Analytical Tools}

\subsection{Recognition and Justice in the City}

The data and the overall understanding of segregation and societal integration are presented and interpreted within the concepts of redistribution, recognition and political representation formulated by Honneth (1995) and Fraser $(1992,2000,2008)$. Honneth identifies three patterns of inter-subjective recognition: love, rights and solidarity. The first pattern concerns basic human relationships, for example love and caring between small numbers of people who are close. The second pattern of recognition is legal: self-respect can only fully develop if individuals are recognised as autonomous actors and receive universal equal treatment. The third element constitutes recognition of self-esteem, given that individuals ascribe to fame, prestige and recognition, and concerns the personal qualities and presentations through which an individual becomes recognised as a person of value to the community. Honneth's theory can be seen as a normative framework of reference for concrete analyses of different forms of recognition and its opposite, disrespect. However, his theory cannot stand alone. When considering the demands of different groups of people for recognition, a theory of justification is also needed. Fraser's theory, which explores a form of justice that requires an equal distribution of recognition and representation, is therefore used to supplement Honneth's.

According to Fraser, it is necessary to devise a three-dimensional concept of justice that can accommodate both defensible claims for social equality and recognition of difference. The leitmotif of Fraser's work is the formulation of a theory of social justice which identifies and defends versions of the cultural politics of difference that can be coherently combined with the social politics of equality and parity in representation.

These three dimensions propose very different concepts of injustice. Redistribution focuses on the injustices it defines as socio-economic, such as being denied an adequate material standard of living, and is rooted in the economic structures of society. Recognition targets the injustices it understands as cultural, which are based on social patterns of interpretation and communication, such as cultural domination and disrespect. Representation serves in part to account for "ordinarily political injustices" which arise internally within bounded political communities when biased decisions compromise the political voice of people who are already considered members and prevent them from fully participating as peers in social interaction.

This study follows Fraser, who maintains that neither distributive justice nor problems of recognition or political representation can be reduced to 
a single issue. She argues for a three-dimensional perspective that includes the perspectives of distribution, recognition and political representation without subsuming any within the others.

Whilst Fraser maintains that the remedy for social injustice may involve the redistribution of income, reorganisation of the division of labour or a more radical transformation of economic structures, the remedy for cultural justice involves some kind of cultural change. This latter point is the core of Mouzelis' concept of polylogic integration. Mouzelis (1995) identifies a range of ideal modes of multiculturalism, highlighting the polylogic integration inspired by Habermas, which respects the autonomy and internal logic of the various cultural identities and traditions whilst also insisting on building a two-way bridge for communications between them.

Titmuss' (1974) concept of positive selectivism is also related to Fraser's concept of redistribution. He has argued that welfare universalism may face problems in meeting the particular needs of specific groups, and that legal equality does not always mean equal treatment. He has therefore proposed that universalism should, in a number of cases, be combined with positive selectivism, in which extra resources would allow for a more equal distribution of income. Thompson and Hogget (1996) have suggested that, in addition to positive selectivism, there should be a particularism that extends beyond the limitations of selectivism, implying a universal/ /egalitarian welfare state with built-in openings for special treatment based on varying standards between specific individuals and groups, thus supplementing the principle of positive selectivism.

The data on poverty is interpreted in this study as "capability failure", formulated by Sen (1992) as restrictions on room for manoeuvre i.e. severe restrictions on the capacity for proactive coping and the possibility of choosing the life the individual wishes to live. Capability failures can be caused by structural, institutional and individual conditions. On an individual level, poor health and poor Danish language skills, for example, play a significant role in the lives of many immigrants and, on a structural and institutional level, a lack of redistribution and recognition reinforces, or is the direct cause of, individual capability failure, especially if this takes the form of discrimination. Capability failure caused by structural and institutional factors - especially those aspects that are experienced as discrimination by immigrants is significant in terms of cultural recognition.

\subsection{Advanced Marginality}

The spatial dimension is an important part of this article and consequently will be addressed using Wacquant's $(1996,2008)$ concept of advanced marginality. 
Wacquant presents advanced marginality as an ideal type of sociohistorical abstraction of real instances of a phenomenon (Weber, 1968: 82-92) which can help us to formulate hypotheses and comparisons (Wacquant, 1996), and singles out six distinctive features: (i) The erosion of the integrative capacity of the wage-labour relationship, which has become a source of fragmentation and precariousness leading to an increase in part-time and precarious jobs and other forms of employment that evade the terms of collective agreements/state regulations. (ii) A functional disconnection from macro-economic trends, meaning that short-term fluctuations in the economy have little impact on areas characterised by advanced marginality. (iii) Territorial fixation and stigmatisation, characterised by increasingly isolated areas being viewed by both insiders and outsiders as social purgatories. (iv) Territorial alienation, which is the obverse of territorial stigmatisation and implies a loss of the place with which marginalised urban populations can identify and where they feel secure. (v) Loss of the safety net which workers could previously fall back on, for example, the social economy within their community, when temporarily rejected from the labour market. (vi) Symbolic and social fragmentation as a result of class decomposition under the pressure of deproletarisation.

\section{A Socio-economic Portrait of Copenhagen: Immigrants and Danes Compared}

The following section presents a brief portrait of the living conditions of immigrants in Copenhagen. As far as possible in terms of the available data, the district of Nørrebro is compared with other districts in the city and/or Copenhagen as a whole.

\subsection{The Changing Class Structure}

Compared with the rest of Denmark, the last two to three decades of class change in Copenhagen have taken a somewhat different turn. Whereas the upper middle class has grown significantly, the working class has shrunk from $57 \%$ in 1985 to $34 \%$ in 2009 in comparison to the national figures of $58 \%$ and $47 \%$, respectively (Olsen et al., 2012). ${ }^{2}$ Within the same period there has only been a small increase, although from a high level, in the industrial reserve army, from 19 to $20 \% .^{3}$ This change in Copenhagen from a genuine working class city to a more middle class

\footnotetext{
2 The definition of the five classes is based on position in the labour force, earnings and education.

${ }^{3}$ In this article, the industrial reserve army is updated from Marx's concept (1971) and is defined as people of working age who have been out of the labour market for more than $4 / 5$ of a year and live on various state benefits, such as early retirement pensions, social assistance and unemployment benefit, or from income earned from different types of activity programmes.
} 
city is also mirrored in housing, which has been considerably upgraded and gentrified (Københavns Kommune, 2013a; Larsen and Hansen, 2012). In the midst of this transformed city there are areas (housing estates) where the industrial reserve army is concentrated, one of which is Nørrebro.

\subsection{The District of Nørrebro}

Nørrebro is one of ten districts in Copenhagen and the one which has the highest population density $\left(18,500\right.$ per $\left.\mathrm{km}^{2}\right)$. Nørrebro has its own specific identity: traditionally, it was a working class area but regeneration and slum clearance programmes, gradually introduced from the 1970s onwards, led to changes in the demography of the area, fuelled by the availability of new social housing which provided opportunities for many young people, students and migrant families to move into the area. By 2009, 27\% of the 78,000 people living in Nørrebro (Københavns Kommune, 2014) were either first or second generation immigrants. More than half of the immigrants come from countries where Muslims are either the majority or a substantial minority (Schmidt, 2012).

A large proportion of the residents are old-age pensioners or belong to the industrial reserve army. In the latter group, the recent decades of liberalism in Danish social policy have resulted in a considerable number of people, particularly long-term recipients of social benefits and immigrants, falling into poverty (Møller, 2011). However, there is also a sizeable group of students and other residents in Nørrebro, mostly living in the outer areas of the district which belong to the middle class and predominantly support left wing politics. In the last municipal elections in 2013, the left wing parties (including the Social Democrats) received $67 \%$ of the vote (Københavns Kommune, 2013b). Nørrebro's increasing social fragmentation, including signs of a labour market precariat (see below), closely corresponds to Wacquant's (1996) characterisation of advanced marginality.

Nørrebro has always been a focus for immigration. One hundred years ago during the era of industrialisation many agricultural labourers settled in the area and in recent decades the majority of immigrants have come from countries with a Muslim majority population (Schmidt, 2012). The residents in Nørrebro have always been known for showing strong solidarity with underprivileged segments of society and have demonstrated against racism and right-wing extremism more than anywhere else in Copenhagen. It is a heavily populated and highly multi-ethnic area with bustling streets and many shops and restaurants run by ethnic minority families. It is also a dynamic area which on several occasions, some dating 
as far back as the 1980s, has been the scene of a number of violent clashes between the police and squatters/autonomous groups. In May 1993, following the Danish "yes" vote to the EU, the Nørrebro district, which had voted a clear "no", was the scene of riots involving police shooting at demonstrators. In spring 2008, the area witnessed one of the worst riots in the history of Denmark, involving young men from predominantly immigrant communities who expressed their frustration with frequent police stop-and-search operations and blamed the police for being "brutal", "racist" and exercising "utterly unacceptable intimidation" (Politiken, 2008).

This, and other similar episodes of fierce rioting involving young immigrants on the streets of Nørrebro, is a far from new phenomenon but has evolved as immigrants have settled there. The way in which immigrants in Nørrebro use the neighbourhood space to do politics can therefore be understood as building on actions that are rooted in history (Schmidt, 2012).

In recent decades, as Nørrebro developed from a traditional working class area into a multi-ethnic and multi-class district, the neighbouring district of Vesterbro has undergone comprehensive gentrification programmes that have transformed it from a typical working class area into a district with a large middle class and high-income group population (Larsen and Hansen, 2012). Moreover, since Vesterbro is the district which borders Nørrebro in the west and the Frederiksberg area, ${ }^{4}$ dominated by the classic urban bourgeoisie, is its north-western neighbour, this contributes, not surprisingly, to establishing Nørrebro as something very specific. It has attracted intense media scrutiny over many years, which has focussed on providing negative reports of a conflict-ridden area and spectacular clashes between the police and immigrants, as well as local groups.

\subsection{Income and Poverty in Copenhagen}

Copenhagen is among the municipalities in Denmark with the lowest average yearly disposable income, which is, on average, 211,400 DKK (Arbejderbevægelsens Erhvervsråd, 2012). However, the internal differences in income are significant. Almost twice as many households in Nørrebro have an income of less than 100,000 DKK than in Copenhagen as a whole and only $4.2 \%$ of Nørrebro households have a yearly income of 700,000 DKK or more, compared to $8.2 \%$ of the households in Copenhagen as a whole.

\footnotetext{
${ }^{4}$ The municipality of Frederiksberg is as autonomous as the other municipalities in Denmark. Geographically, however, it is surrounded on all sides by the city of Copenhagen.
} 
A study of Nørrebro based on register data measuring the incomes of young people (aged 15-24) from employment, education ${ }^{5}$ and activation programmes (CASA, 2013) reveals remarkable differences. The majority of young Danish people are either employed or in education and only 10 to $15 \%$ have no registered income, whereas the corresponding figure for young immigrants is around $50 \%$. The data does not supply information on whether this half of the immigrant youth are provided for by the family or live off the black economy or criminal activity. However, it underlines the relevance of advanced marginalization, in which the inhabitants may or may not be able to rely on collective informal support, whilst at the same time developing "self-provisioning", strategies, "shadow work" underground trading and quasi-institutionalised "hustling" (Wacquant, 1996: 127).

\subsection{Poverty}

In 2009, Copenhagen was the municipality with the highest percentage of poor people, totalling $7.6 \%$ in comparison to $4.4 \%$ for Denmark as a whole (excluding students) (Arbejderbevægelsens Erhvervsråd, 2011a). ${ }^{6}$

The poor population in Copenhagen is very unevenly spread throughout the different districts and parishes of the city. Two of the five parishes with the highest poverty rates are located in Nørrebro, with poverty rates of 10.1 and 9.8\% respectively (Arbejderbevægelsens Erhvervsråd, 2010a).

In 2005, adding together the poverty percentages for immigrants and their descendants, $30 \%$ of all immigrants and their descendants lived in poverty, compared with $17 \%$ of Danes. ${ }^{7}$

\subsection{Health}

Immigrants have a much greater need for health care services than Danes but often have difficulties in crossing certain informal barriers in the health care system due to lack of knowledge of the relevant health care services, for example, or language barriers when communicating with health care staff (Holmberg et al., 2009).

Among the ten Copenhagen parishes with the highest concentration of people with poor health, three are located in Nørrebro (Arbejderbevægelsens Erhvervsråd, 2010b). Here, the use of doctors and the cost of medicines are,

\footnotetext{
${ }^{5}$ People in education aged over 18 receive a monthly grant from the state.

${ }^{6}$ The poverty line is defined as $50 \%$ of the median income.

7 The data comes from "The Copenhagen Survey" (Københavns Kommune, 2008) and should not be compared with the above-mentioned poverty data since the latter is constructed using the budget method and has a higher (and more generous) poverty line than the one based on $50 \%$ of the median income.
} 
on average, 2.5 times higher than for the whole population of Copenhagen. As a part of the Copenhagen City Council integration policy (see below), there is a separate strategy for health care for immigrants.

\subsection{Housing}

The so-called "ghetto list" recently constructed by the government shows the public housing areas that are characterized by two out of the following three criteria: (i) $50 \%$ or more of the residents are immigrants; (ii) more than $40 \%$ of the residents are not active in the labour market or education system; (iii) a high crime rate (Ministeriet for By, Bolig og Landdistrikter, 2012). Of the 33 areas listed in 2012, eight are located in Copenhagen and three of them are in Nørrebro. These "neglected" housing areas are not ethnically homogeneous but are to a large extent inhabited by Danes not included in the labour market. It could be argued that the "ghetto list" is both a blessing and a curse. One the one hand, these areas attract special political attention and also investments in employment, education, housing improvements, etc. On the other hand, it also tends to stigmatize them. Generally, however, it is problematic to characterize housing areas in Denmark as "ghettos" (culturally uniform socio-spatial ensembles based on the forcible relegation of stigmatized populations who develop groupand place-specific organizations (Wacquant, 1996): it is preferable to use Wacquant's concept of advanced marginality which, in addition to stigmatisation by the surrounding society, includes several of the characteristics of neglected housing areas (cf. above and below).

\subsection{Education}

Copenhagen City Council uses an "integration barometer" (Københavns Kommune, 2011) to measure how well migrants and Danes fare in different areas, such as school grades, unemployment, safety and discrimination.

In terms of school grades, both boys and girls from immigrant families perform less well than Danes. Nørrebro is the city district with the most pronounced segregation in state schools, since all four schools in the barometer deviate by at least $10 \%$ from the population average for immigrant children - with two schools having a higher percentage and two lower than the average. ${ }^{8}$

\footnotetext{
${ }^{8}$ There are seven state schools in Nørrebro but there are also many private schools in the area. In inner Nørrebro, $41 \%$ of pupils attend private schools and this creates a self-perpetuating process in which high income families remove their children from the state schools (attended by many children from less well-off families and/or children of immigrants) and place them in private schools (with other well-provided-for children from middle class homes).
} 
In particular, young men from immigrant families do not receive any youth training. Almost $40 \%$ of them have not had any youth training by the age of 26 (Arbejderbevægelsens Erhvervsråd, 2011b). They appear to be severely marginalized; compared to Danes, twice as many are not involved in educational activities or are not employed. One of the severe problems for migrant youth who participate in youth training programmes is finding a workshop for job training - an obligatory part of the youth training programme. This explains why so many do not start or finish a programme. Again reflecting advanced marginality, the social fragmentation of the labour force is underlined.

\subsection{Participation in the Labour Market}

Large differences are found when comparing the immigrant unemployment rate with the total for all inhabitants of Copenhagen. In 2011, the unemployment rate for immigrant women was more than 1.5 times higher than the rate for all women in Copenhagen, while for men it was more than twice as high. ${ }^{9}$

In Nørrebro, $80.2 \%$ of Danes were employed in 2011, compared to $48.3 \%$ of immigrants and $68.9 \%$ of their descendants. $16.2 \%$ of Danes were not included into the labour market, compared to $46.7 \%$ of immigrants and $26.6 \%$ of their descendants. ${ }^{10}$ The huge differences in the labour market underline the social fragmentation of the labour force, clearly reflecting advanced marginality (Wacquant, 1996), and explain a great deal of the differences in the poverty rates.

\section{Inclusion Policies in Copenhagen}

Copenhagen City Council has been more active than most Danish municipalities in creating and pursuing an integration policy for immigrants (and other minorities) both in terms of religious, cultural and economic recognition. The first major integration programme was implemented in 2007, since the City Council recognized that Copenhagen had become a multi-ethnic city in recent decades, and stated that ethnic diversity has "the potential to improve Copenhagen's status as a large city in a constantly changing diversified world" (Københavns Kommune, 2007-2010).

\footnotetext{
9 Authors' calculations, based on the Copenhagen Municipality Statistical Bank.

${ }^{10}$ Groups not included in the labour market are, for example, pensioners who have taken early retirement and those receiving social assistance. Children, students and old-age pensioners are not included in the calculations.
} 


\subsection{The Three Principles}

The programme contains three integration policy principles: (i) Diversity is strength: the diversity of the Copenhagen population can be used positively, for example, in the workplace, and the ability to use two languages is a strength. (ii) Everybody should have the opportunity to participate and be treated equally but not necessarily in the same way, thus drawing on Titmuss' (1974) concept of positive selectivism to state that if individuals need extra help to be able to participate they shall receive it. (iii) Mouzelis' (1995) ideal of polylogic integration is exemplified when the programme states that "Citizenship concerns everybody. Everybody has a responsibility for inclusion, and if more people are to identify themselves as Copenhageners, partnerships should be established across the city in which everybody contributes and assumes responsibilities" (Københavns Kommune, 2011-2014: 7).

The policy has four main target areas with specific goals: 1) All children and young people should have a decent start: as demonstrated above, boys from immigrant families in particular leave the education system without any youth training. 2) Inclusion in the labour market: given the employment situation for migrants in Copenhagen analysed above, it comes as no surprise that immigrant employment is a main point. 3) Fraser's (1992, 2000) principle of redistribution is exemplified when the City Council states that socially vulnerable people and areas in the city should be given a helping hand, focusing in particular on enabling more children of migrants to attend day care and other child and youth facilities. 4) An open and accommodating metropolis: the goals here include less exclusion from involvement in community life due to poverty, and less discrimination. As demonstrated below, the experience of discrimination is especially high among immigrants and their descendants.

As a policy programme for integration, the plan must be characterized as both ambitious and coherent, containing detailed action plans and devolution of responsibility for each vision and policy goal to the different municipal departments. The City Council's integration policies include, as already shown, some of most important analytical tools used in this article. Fraser's concept of recognition (of immigrants, other minority groups and vulnerable people and areas) runs through the whole document and is a very central part of the integration policy. In addition, Titmuss' (1974) concept of positive selectivism and Thompson and Hogget's (1996) concept of particularism are frequently applied. Another central principle of the policy is to increase the involvement of all citizens and thereby contribute towards better communication between immigrants and Danes, which again can lead to greater recognition and 
acceptance of each other's norms and values - Mouzelis' (1995) two-way bridge of communication. However, the City Council also recognizes that socio-economic conditions and inequalities are central issues. Nevertheless, in terms of Fraser's concept of redistribution policies, the City Council has its "hands tied" in many cases and the redistribution of income in particular is mainly decided on a national level. This could be perceived as a structural capability failure in Sen's (1992) understanding, in the sense that it severely restricts the City Council's room for manoeuvre.

The focus of the next section, concerning advanced marginality (Wacquant, 1996), will be on the City Council's recognition, economic redistribution, positive selectivism and particularism towards Nørrebro, as well as non-discriminatory, two-way communication arrangements between Danes and immigrants.

\section{Recognition, Redistribution, Positive Selectivism, Particularism and Polylogic Integration in Nørrebro}

\subsection{Data from the Nørrebro Study}

Within Copenhagen, a spatial study was recently carried out in the Nørrebro district. The study forms part of the reports prepared by the At Home in Europe project by the Open Society Foundations, in cooperation with local/national experts (At Home in Europe Project, 2011). Among other things, the Nørrebro study sheds light on day-to-day interactions between immigrants and Danes and thus provides empirical data which illustrates several of the themes central to this article: recognition, redistribution, positive selectivism, particularism and polylogic integration.

The study data has to be interpreted with some caution. The core data consists of face-to-face questionnaire interviews with 100 self-defined Muslim residents and 100 non-Muslims from Nørrebro. The sample frame was designed to target maximum representation of the various ethnic-national communities of Muslims as well as non-Muslims (91 out of 100 are Danes), and was sub-sampled by age and gender. It is therefore not a random sample but a quota sample, and none of the groups are big enough to be representative. Another problem concerning representativity is the fact that the data was collected using the snowball method.

As the study acknowledges, Muslims do not constitute a homogenous group with fixed boundaries - although they are currently usually defined as such in national popular political and public discourses. One example of heterogeneity can be found within education, where a survey (Mikkelsen, 2001) found that immigrants from Iran and their descendants are much better educated than those from Somalia and the former Yugoslavia. 
Data was also collected from six focus groups with self-identifying local Muslims. Each group discussed the following issues: education and employment; health and social services; policing; civil and political participation; everyday life; being citizens of the city. Finally, eight in-depth interviews were held with local officials, experts on integration and representatives from NGOs. Further data was collected from academic research, policy documents and reports from international and domestic organisations to supplement the data from the At Home in Europe project.

\subsection{Recognition, Redistribution, Positive Selectivism, Particularism, Political Representation and Polylogic Integration}

Turning to the themes of recognition, redistribution, positive selectivism, particularism and polylogic integration, it is important to observe that although they are all distinct analytical concepts, their concrete manifestations often reveal connections, as we shall see.

Regarding recognition, Fraser $(1992,2000)$ emphasised that if individuals are to be recognised as autonomous acting subjects and receive universal equal treatment, they have to be ascribed the same moral status as all others. Here, contrary to the national public discourse and social policy, the data shows that there is a greater sense of mutual acceptance than distance between the two groups (Muslims and non-Muslims). The majority of respondents in both groups agreed that people from different backgrounds could get along well together in their local area, thereby confirming Mouzelis' (1995) concept of polylogic integration in which the autonomy and internal logic of cultural identities and traditions are respected, whilst insisting on a two-way bridge for communications.

Only $1 / 3$ of the Muslims see themselves as Danish and a little more than $10 \%$ believe that others see them as such, whereas half want to be seen by others as Danish. These observations, together with the observations below concerning the frequency of interactions between Muslims and non-Muslims in the district, challenge one of the most popular perceptions in the national and media discourse that some residential areas, including Nørrebro, are developing into isolated "ethnic enclaves" resulting in a "parallel society" - with Muslims implicitly held responsible for their isolation from wider society and lack of willingness to integrate (Andersen et al., 2009). This stigma of space, as viewed by outsiders, corresponds closely to Wacquant's (1996) concept of advanced marginality.

The specific nature of the City Council policy on immigrants and integration is underlined within the field of education. Whereas national legislation has abolished government support for mother tongue tuition for 
students originating from outside Europe, Copenhagen has decided to continue its principle of positive selectivism, formulated by Titmuss (1974) as a system by which the needs of specific groups can be met by providing extra resources, in this case by offering mother tongue tuition on an almost equal basis for all bilingual students. A range of other concrete positive selectivism measures have also been introduced, for example, language stimulation activities in kindergartens and preschools, community centres financed by the municipality which include cafes and bars with subsidised rates for food and beverages, and support for schools to access updated computer-based learning facilities.

Other positive selectivism or redistribution programmes have been launched involving the upskilling of more than 1000 teachers in teaching Danish as a second language and courses in multilingualism and inter-culturalism. In addition, when parents participate in language centre activities they are compensated for the cost of their transport. The main general hospital in Nørrebro has also established a common prayer room and an imam is available to provide support for patients and their families.

Sen (1992) defines poverty as capability failures that constitute severe restrictions on the capacity for proactive coping and the opportunities to choose the life one wishes to live. In order to combat widespread poverty among immigrants, as shown above, the City Council has taken the initiative to offer capacity-building support for NGOs and other organisations providing information and advice to immigrant communities.

The City Council also applies particularism programmes which take Titmuss' (1974) concept of positive selectivism as their starting point but extend it to include built-in openings for special treatment for the varying standards involving specific individuals and groups (Thompson and Hoggett, 1996). One example of particularistic programmes is the support for Danish language tuition for older immigrant women.

Political representation is formulated by Fraser (2008) as parity of representation which serves to account for "ordinarily political injustices" that arise internally within bounded political communities when biased decisions compromise the political voice of some who already count as members, impairing their ability to participate as peers in social interaction. Figures from the 2009 municipal election (municipal suffrage is confined to immigrants from outside the EU and Nordic countries who have been resident for over three years) show that 6 of the Copenhagen City Council's 55 members come from an immigrant background, equivalent to $11 \% .{ }^{11} 14.6 \%$ of the

$\overline{11}$ Authors' calculations, based on council members' non-Western names only. 
entire population of Copenhagen, are immigrants and descendants (with or without the right to vote) (Københavns Kommune, 2014). There is also a broader dimension to political representation in the form of Copenhagen's 12 local district councils, whose members are elected not only through political parties but also via local civic organisations such as associations based on ownership of property, commercial organisations, schools, day care centres, environmental associations, etc. These local district councils often have around 20 members and the representation of immigrants is, on an average, around $5 \%$. However, this varies widely, ranging from some districts in which immigrants are not represented at all to the largest representation, in the district of Nørrebro, totalling around $20 \%$ of their share of the inhabitants. ${ }^{12}$

Although Togeby's (2003) information on non-Western immigrant members indicates growing representation on a municipal, regional and parliamentary level, it should be noted that the figures for political representation are numerical only and do not say much about the representatives' real political influence. Moreover, although the immigrant members of the municipal councils function as bridges - in Mouzelis' (1995) understanding of the two way bridge of integration - between immigrant groups and Danish society, the figures fall short of what Fraser (2008) calls the "all-affected principle" which holds that all those affected by a given social structure or institution have a moral standing as subjects of justice in relation to it. Nevertheless, as Mikkelsen (2011) points out, it is also important to note that immigrants' political influence is exercised to quite a large extent through various organisations and associations, including solidarity-based organisations that have both immigrant and Danish members, as well as through private and semi-official support organisations.

\subsection{Discrimination}

There are, of course, also examples from Nørrebro of the opposite of recognition, which Honneth (1995) calls disrespect or non-recognition and which in everyday language is often labelled discrimination. This seems to be particularly prevalent in education. It is reported that many teachers have low expectations of children from migrant families and that some Arabic-speaking parents felt that Arabic, like Spanish and French, should be included in formal education, rather than just as an extracurricular activity. It should also be acknowledged that many Danes from Nørrebro move their children to private schools in order to avoid state schools with a high proportion of bilingual pupils.

${ }_{12}$ The authors' calculations here are also based on members' names. 
In general, however, the data on discrimination from the spatial study of Nørrebro is rather weak and uncertain and, with regard to the labour market in particular, very opaque. Sample respondents who had been rejected for jobs were asked about the reasons why they had been unsuccessful and around $1 / 3$ of the immigrants cited their ethnic or religious background as the most important factor. Here again, however, the number is very small. There is also some, albeit weak, evidence of discrimination in housing experienced by immigrants, in particular concerning private housing association waiting lists. Extending beyond the district of Nørrebro, the Integration Barometer (Københavns Kommune, 2011), which includes all of Copenhagen's 10 districts, shows that immigrants experience discrimination three times as often as Danes and that the difference is even higher among men.

\subsection{Health and Policing}

Somewhat opposite conclusions can be drawn regarding Nørrebro's health service, with a large majority of immigrants expressing satisfaction with the service and stating that it respects and recognises different religious customs. A number of immigrant doctors have recently been employed at the district's central hospital, which has helped to improve cross-cultural understanding in the hospital. Only a small minority complained about the lack of interpreter facilities.

Among the institutions that stamp their imprint on the daily life of the population and the climate of "problem neighbourhoods", special attention must be paid to the police. When asked about policing in Nørrebro, the picture also becomes somewhat blurred. On the one hand, in 2008 the police immigrant profiling practice used in the search for drugs and weapons resulted in complaints about the disproportionate use of police stop-and-search operations on young men from immigrant families and led to claims that they were "brutal", "racist" and used "utterly unacceptable intimidation" (Politiken, February 18, 2008). On the other hand, the sample data showed that the majority of immigrants were either fairly or very satisfied with policing in the district, including those who had come into contact with the police during the course of the previous year. The study also revealed that both immigrants and Danes had a fair or a lot of trust in the police.

\section{Interaction, Participation, Citizenship and Advanced Marginality}

The themes of interaction, participation and citizenship are all, in different ways, under different conditions and with mutual interrelations, connected 
to the concept of recognition as conceived by Honneth (1995). They may all lead to increased recognition within one or more of Honneth's three dimensions of recognition. At the same time, increasing recognition may be followed by increased interaction, participation and citizenship. These two virtuous cycles are both examples of Mouzelis' (1995) polylogic integration in which the two-way bridge is built up through interaction between immigrants and Danes, their involvement in each other's activities, a form of citizenship that implies, among other things, the same political and legal rights for every individual and, finally, more effective bridge-building through recognition.

In the Nørrebro study, both immigrants and Danes reported frequent daily and weekly interactions with people from different ethnic and religious background. There was also a clear sense of belonging to, and identification with, Copenhagen and Nørrebro, among both the immigrants and the Danes. The majority of both immigrants and Danes say that some or most of the people in the neighbourhoods can be trusted and that they enjoy living in the area and believe that neighbours get on well together and are willing to help one another. These observations conflict with Wacquant's concept of advanced marginality, in which not only outsiders but also insiders view the area as consisting of "social purgatories and urban hell holes where only the refuse of society would accept to dwell" (Wacquant, 1996: 125). However, Wacquant continues, whether or not those areas are in fact dilapidated, dangerous and declining matters little. The prejudiced belief that they are suffices to produce detrimental consequences: a muted feeling of guilt and shame whose unacknowledged weight warps human relations. Supported by empirical data, Wacquant claims that people commonly hide their address, avoid having family and friends visit them at home, and feel compelled to make excuses for residing there. The obverse of this, Wacquant continues, is the dissolution of place "that is the loss of a locale marginalised urban populations identify with and where they can feel secure" (ibidem: 126).

In terms of these key aspects of territorial stigmatisation and territorial alienation the overall picture of Nørrebro is quite far removed from Wacquant's concept of advanced marginality, but is also far from ideal, given the above references to discrimination, and the long-term trend in the national media in recent decades which has increasingly portrayed the district as conflict-ridden and dangerous. However, the general conclusion is that Danes living in Nørrebro, where they have frequent daily interaction with individuals from immigrant minorities, are far less biased towards immigrants than Danes living in provincial towns and areas. Similar results have been demonstrated in the Netherlands and UK (Hartmann and 
Husband, 1974) and by Frølund Thomsen (2012) and Rafiqi and Frølund Thomsen (2014), who emphasise the importance of neighbourhood and workplace interactions in particular in terms of the majority's tolerance towards minorities. It therefore seems to be a quite well-supported hypothesis that the two-way communication bridge both assumes and furthers recognition. Data from the Nørrebro study shows that there is a clear sense of belonging to, and identification with, Nørrebro among both immigrants and Danes. Most people in both groups are satisfied with living in the area, again an observation that scarcely reflects Wacquant's understanding of "spatial alienation".

As far as participation is concerned, the data is rather limited and focuses mainly on voting. The results from the sample show that most of the immigrants eligible to vote exercised this right in both national and local elections. However, corresponding with the results from other studies (for example Van Dijk, 1987), the turnout for Danes tended to be higher than for immigrants. Similarly, a higher proportion of Danes than immigrants had taken part in other political activities, such as attending a public rally or demonstration (Elklit et al., 2005; Mikkelsen, 2008).

However, it is again important to note that immigrants' political influence is exercised to quite a considerable extent through various organisations and associations, including solidarity-based organisations with both immigrant and Danish members, as well as through private and semi-official support organisations (Mikkelsen, 2011).

\section{Perspectives}

Since the mid 1990s Copenhagen has been a growing entrepreneurial city, but in the same period there has also been a growing divide in terms of issues such as employment, incomes and housing - especially between upper middle class Danes and immigrants. This is also evident in the spatial segregation between well-off city districts and unemployment- and poverty-ridden districts with a high concentration of immigrants. Nørrebro belongs to the latter type.

Throughout the article we have related to Wacquant's ideal formulated concept of advanced marginality to the district of Nørrebro. On the one hand, it is clearly an area where most of the residents belong to the working class, are immigrants, belong to one of the many sectors of the industrial reserve army or else are lower middle class or students. The social fragmentation of the population is high. It is also an area where territorial stigmatization by outsiders is evident - in the media, via politicians and in discourses other than those of the Copenhagen City Council. 
On the other hand, it differs from Wacquant's portrait of advanced marginality in terms of the lack of any feeling of stigmatization on the part of the residents and, conversely, their sense of belonging to the district. There are no indications of territorial alienation or residents hiding their address and avoiding family and friends visiting them at home, nor is there any data indicating the loss of any safety net to fall back on in situations of temporary unemployment. The residents' feeling of belonging is likely to be related to fair political representation, the City Council's recognition of Nørrebro's cultural and socio-ethnic specificities and the relatively comprehensive redistribution and positive selectivism in the district. Erosion of trust, which is one of the basic characteristics of advanced marginality, is not evident in Nørrebro where there is considerable interaction, mutual confidence and recognition between immigrants and native Danes. Moreover, there are no restrictions on outsiders moving into/working in the area or vice versa, as far as local residents are concerned. Even though parts of Nørrebro are portrayed as "dangerous places" with "dangerous male ethnic minority gangsters" in the media, the ordinary Copenhagener does not feel and experience Nørrebro as a no-go zone.

The economic future for Copenhagen seems bright, since more and more well educated young people with jobs and high incomes are expected to move there, paving the way for new investments and improvements in the city. However, the city also risks becoming even more fragmented, since the data from Nørrebro indicates that many young people from migrant backgrounds, especially young men, do not get an education. They may form a precariat (Wacquant, 2007; Standing, 2011), facing insecure work, low wages and greater competition from low-waged migrant workers from (East) European countries within the European Union. Within Copenhagen, the future may reveal an even more segregated labour market with well-paid jobs for the upper middle class on the one hand, and insecure badly-paid jobs for unskilled workers on the other hand. The development of an increasingly poor working precariat is therefore not unthinkable.

Revised by Sheena Caldwell

\section{References}

Andersen, Hans T.; Winther, Lars (2010), "Crisis in the Resurgent City? The Rise of Copenhagen”, International Journal of Urban and Regional Research, 34(3), 693-700. Andersen, John; Larsen, Jørgen E.; Møller, Iver H. (2009), “The Exclusion and Marginalisation of Immigrants in the Danish Welfare Society", International Journal of Sociology and Social Policy, 29(5/6), 274-286. 
Arbejderbevægelsens Erhvervsråd (2010a), Øget økonomisk ghettoisering i Danmarks storbyer. København: Arbejderbevægelsens Erhvervsråd.

Arbejderbevægelsens Erhvervsråd (2010b), Uligheden $i$ sundhed skærer igennem Danmarks storbyer. København: Arbejderbevægelsens Erhvervsråd.

Arbejderbevægelsens Erhvervsråd (2011a), Fattigdommen rammer skævt $i$ Danmark. København: Arbejderbevægelsens Erhvervsråd.

Arbejderbevægelsens Erhvervsråd (2011b), Mere end bver 3. Indvandrerdreng i Danmark fär ingen uddannelse. København: Arbejderbevægelsens Erhvervsråd.

Arbejderbevægelsens Erhvervsråd (2012), Stigende indkomstforskelle i København. København: Arbejderbevægelsens Erhvervsråd.

At Home in Europe Project (2011), Muslims in Copenhagen. London: Open Society Foundations.

CASA (2013), Analyse af uddannelses- og beskxftigelsesindsatserne rettet mod unge pa Nørrebro. København: CASA.

Danmarks Statistik (2013), Indvandrere i Danmark. København: Danmarks Statistik.

Elklit, Jørgen; Møller, Birgit; Svensson, Palle; Togeby, Lise (2005), Gensyn med sofavxlgerne. Valgdeltagelse i Danmark. Aarhus: Department of Political Science, Aarhus Universitet.

Fraser, Nancy (1992), "Recognition and Redistribution”, New Left Review, 2, July-August, 68-93.

Fraser, Nancy (2000), "Rethinking Recognition”, New Left Review, 3, May-June, 107-120.

Fraser, Nancy (2008), Scales of Justice: Reimagining Political Space in a Globalizing World. New York: Columbia University Press.

Frølund Thomsen, Jens P. (2012), "How Does Intergroup Contact Generate Ethnic Tolerance? The Contact Hypothesis in a Scandinavian Context", Scandinavian Political Studies, 35(2), 159-178.

Hansen, Høgni K.; Lars Winther (2010), “The Spaces of Urban Economic Geographies: Industrial Transformation in the Outer City of Copenhagen”, Danish Journal of Geograpby, 107(2), 45-48.

Hartmann, Paul; Husband, Charles (1974), Racism and Mass Media. London: Davis-Poynter.

Holmberg, Teresa; Ahlmark, Nana; Curtis, Tine (2009), "State of the Art Report”. Etniske minoriteters sundhed $i$ Danmark. København: Statens Institut for Folkesundhed.

Honneth, Axel (1995), The Struggle for Recognition: The Moral Grammar for Social Conflict. Cambridge: Polity Press.

Københavns Kommune (2007-2010), Integration Policy 2007-2010. København: Københavns Kommune, Beskæftigelses-og Integrationsforvaltningen.

Københavns Kommune (2008), Analyse af levevilkair og fattigdom i Københavns Kommune. København: Københavns Kommune, Socialforvaltningen, Projektkontoret. 
Københavns Kommune (2011-2014), Integration Policy 2011-2014. Bland dig i byen. Medborgerskab og Inklusion. København: Københavns Kommune, Beskæftigelses- og Integrationsforvaltningen.

Københavns Kommune (2011), Integration Barometer. Bland dig i byen. København: Københavns Kommune, Beskæftigelses- og Integrationsforvaltningen.

Københavns Kommune (2013a), Boligbarometer 2013 - Faktaark; 2013. København: Københavns Kommune.

Københavns Kommune (2013b), BR-valget den 19. november 2013. København: Københavns Kommune.

Københavns Kommune (2014), Faktaark fra Københavns Kommune. Befolkningen efter berkomst og bydele. 1. januar 2014. København: Københavns Kommune.

Larsen, Henrik G.; Hansen, Anders L. (2012), "Retten til byen”, in John Andersen et al. (eds.), Byen i bevægelse. Mobilitet-Politik-Performativitet. Frederiksberg: Roskilde Universitetsforlag, 131-147.

Majoor, Stan J. H. (2008), "Progressive Planning Ideals in a Neo-liberal Context: The Case of Ørestad Copenhagen”, International Planning Studies, 13(2), 101-117.

Marx, Karl (1971), Kapitalen. København: Bibliotek Rhodos.

Mikkelsen, Flemming (2001), Integrationens Paradoks. København: Catinet.

Mikkelsen, Flemming (2008), Indvandring og integration. Copenhagen: Akademisk Forlag. Mikkelsen, Flemming (2011), Transnational identitet under forandring. København: Museum Tusculanums Forlag.

Ministeriet for By, Bolig og Landdistrikter (Ministry of City, Housing and Rural Districts) (2012), Liste over særligt udsatte boligområder pr. 1. oktober 2012. København: Ministeriet for By, Bolig og Landdistrikter.

Mouzelis, Nicos (1995), Strategies for Integration and Socio-Cultural Differentiation. CID studies no. 11, Centre for Social Integration and Differentiation. Copenhagen: Copenhagen Business School.

Møller, Iver H. (2011), “Liberalismens Socialpolitik”, in Iver H. Møller; Jørgen E. Larsen (eds.), Socialpolitik. København: Hans Reitzels Forlag, 491-508.

Olsen, Lars; Ploug, Niels; Andersen, Lars; Juul, Jonas S. (2012), Det danske klassesamfund. Et socialt Danmarksportræt. København: Gyldendal.

Politiken (large daily Danish newspaper) (2008), Boys from Inner Nørrebro: The truth behind the Riots. 18 February 2008.

Rafiqi, Arzoo; Frølund Thomsen, Jens P. (2014), "Når majoritetsmedlemmer og etniske minoritetsmedlemmer mødes”, Dansk Sociologi, 25(1), 83-99.

Sen, Amartya (1992), Inequality Reexamined. Oxford: Clarendon Press.

Schmidt, Garby (2012), "Grounded Politics: Manifesting Muslim Identity as a Political Factor and Localized Identity in Copenhagen”, Ethnicities, 12(5), 603-622.

Standing, Guy (2011), The Precariat. The New Dangerous Class. New York: Bloomsbury Academic. 
Thompson, Simon; Hoggett, Paul (1996), "Universalism, Selectivism and Particularism.

Towards a Post-Modern Social Policy”, Critical Social Policy, 16(26), 21-43.

Togeby, Lise (2003), Fra fremmedarbejdere til etniske minoriteter. Århus: Aarhus Universitetsforlag.

Titmuss, Richard (1974), Social Policy. London: Allen and Unwin.

Van Dijk, Teun A. (1987), Communicating Racism: Ethnic Prejudice in Thought and Talk. London: Sage.

Wacquant, Loïc (1996), “The Rise of Advanced Marginality: Notes on its Nature and Implications", Acta Socioligica, 39(2), 121-139.

Wacquant, Loïc (2008), Urban Outcasts. A Comparative Sociology of Advanced Marginality. Cambridge: Polity Press.

Wacquant, Loïc (2007), "Territorial Stigmatization in the Age of Advanced Marginality”, Thesis Eleven, Number 91, 66-77.

Weber, Max (1968), Economy and Society: An Outline of interpretative Sociology. New York: Bedminster Press.

Winther, Lars (2007), "Location Dynamics of Business Services in the Urban Landscape of Copenhagen: Imaginary Spaces of Location”, BELGEO, 1, 51-72.

Received on 17.02.2015

Accepted for publication on 14.07.2015

Iver Hornemann Møller

Linneuniversitetet, Växjö 351-95, Sweden

Contact: iverhm@hotmail.com

Jørgen Elm Larsen

Department of Sociology, University of Copenhagen

Øster Farimagsgade 5, Bld. 16, DK-1014 Copenhagen K, Denmark

Contact: jel@soc.ku.dk

\section{A segregação racial e socioeconómica nas condições de vida em Copenhaga} $\mathrm{O}$ presente artigo tem como objetivo a análise das discrepâncias entre alguns aspetos das condições de vida de grupos étnicos dinamarqueses e imigrantes em Copenhaga, uma cidade bastante próspera e bem posicionada em termos da economia

\section{La ségrégation raciale et socioécono-} mique dans les conditions de vie à Copenhague

Le présent article a pour but d'analyser les différences entre certains aspects des conditions de vie de groupes ethniques danois et immigrants à Copenhague, une ville assez prospère et bien classée dans 
global, mas que, recentemente, tem vindo a experimentar cada vez mais a pobreza e a segregação racial. As discrepâncias de rendimentos levaram a um aumento da segregação espacial em Copenhaga em termos de habitação e educação. Tal segregação é mais patente em relação aos dinamarqueses mais qualificados e aos imigrantes de países não ocidentais. $\mathrm{O}$ artigo analisa, em primeiro lugar, a pobreza a nível dos agregados familiares e as suas dimensões espaciais. Em segundo lugar, aborda outras condições de vida (as redes sociais, por exemplo). Em terceiro lugar, explora as experiências a nível de educação, emprego e cidadania, entre outros. Conclui-se que, a manter-se a segregação, a coesão social em Copenhaga poderá estar ameaçada.

Palavras-chave: condições de vida; Copenhaga (Dinamarca); imigrantes e dinamarqueses nativos; pobreza; segregação. l'économie mondiale mais qui en vient de plus en plus à pâtir de pauvreté et de ségrégation raciale. Les écarts de revenus ont conduit à une croissance de la ségrégation spatiale à Copenhague en matière de logement et d'éducation. Cette ségrégation est plus marquée entre les danois les plus qualifiés et les immigrants de pays non occidentaux. L'article se penche en premier lieu sur la pauvreté au niveau des foyers et de leurs dimensions spatiales. En deuxième lieu, il aborde d'autres conditions de vie (les réseaux sociaux, par exemple). En troisième lieu, il examine, entre autres, les expériences au niveau de l'éducation, de l'emploi et de la citoyenneté. Il en conclut que si la ségrégation perdure, la cohésion sociale à Copenhague pourrait être menacée.

Mots-clés: conditions de vie; Copenhague (Danemark); immigrants et danois natifs; pauvreté; ségrégation. 
